\title{
“Asyhurul Hurum" Tirakat Education in Exact Science Perspectives, Social, Psychology.
}

\author{
D Hartono $^{1}$, R Jannah ${ }^{2}$, N Azizah ${ }^{3}$ \\ ${ }^{1}$ IAI Al-Khoziny Surabaya, Indonesia \\ ${ }^{2,3}$ Science Department, Universitas Negeri Surabaya \\ Email: djokohartono70@yahoo.co.id
}

\begin{abstract}
Everyone, especially students from the Jagad 'Alimussirry Surabaya Islamic Boarding School, is indispensable for everyone, especially the students of the' Alimussirry 'Jagad Islamic Boarding School. Tirakat is studied from the perspective of exact science, social, and psychology. Tirakat is applied to train students to improve emotional intelligence, improve the brain's working system, and increase the sense of empathy for others. This research uses a cognitive paradigm with a qualitative approach. Literature review and interview methods were used to obtain research data. Interviews were conducted with 15 students. The results of this study state that inexact science, Tirakat Asyhurul Hurum can increase concentration in learning, increase metabolism, and increase immunity. Socially, Tirakat Asyhurul Hurum can increase feelings of empathy for others and Tirakat Asyhurul Hurum. psychologically able to increase emotional intelligence in a person.
\end{abstract}

Keywords: Asyhurul Hurum, tirakat, exact science, social, psychology.

\section{INTRODUCTION}

Religion as a cultural system according to Greetz is explained with five important points which are the reasons for his theory, namely: 1 .) a symbol system that plays a role or aims, 2.) builds a strong mood, pervasive (easily spreads), is durable and does not easily fade or disappearing in humans by, 3.) formulating a general conceptual order, 4.) placing these conceptions with an emanation of factuality, 5.) which later these conceptions will appear realistic and unique [1].

Islam is a perfect religion, its perfection is reflected in the arrangement of all the joints of the perfection of human life. Islam also regulates not only zahir matters but also regulates mental matters such as how to obtain peace and happiness in the world and the hereafter and the blessings of all nature (rahmatan-lil'alamin). Therefore, in the Shari'a there must be benefits, in everything beneficial (of course in human eyes) is not necessarily according to the Shari'a like tirakat.

Tirakat in the big Indonesian Dictionary (KBBI) means "To hold back lust (such as fasting, abstaining) [2]. From this definition, it can be understood that the concept of tirakat is also found in every religion. In each religion, there is a different concept of tirakat. In the world of boarding school, penance is manifested in the behavior of fasting, eating as long as you are full, and even avoiding satiety. The purpose of this tirakat is worship which is manifested by a simple life behavior.

Tirakat can be said to be part of the style of Sufism (Islam) which is practiced by the Javanese. In the context of modern life today, the practice of tirakat is not a part of human life in general. Sufism is a very positive form of escape for people experiencing spiritual aridity 
and frustration. At such times, science is unable to describe the explanation of human existence and the world, as well as the successes and failures in human life, so the practice of tirakat is used as one of the lives of religion which is considered a way that can provide an explanation as well as a solution to the problems of human life.

Asyhurul hurum is a place to do penance which is usually done by various Islamic boarding schools. Asyhurul Hurum is a month that is glorified by Allah SWT. Allah subhanahu wa Ta'ala said:

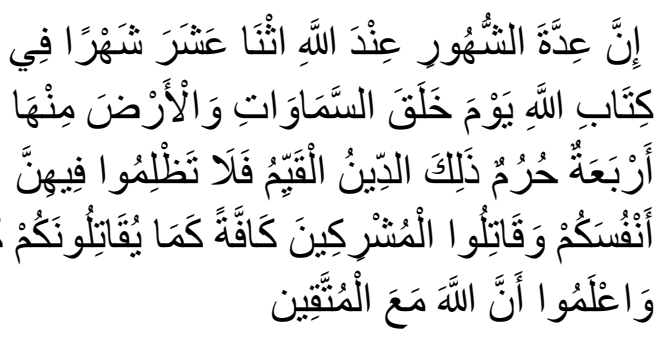

"Indeed, the number of months in the (law) of Allah is twelve months, (which has been set) in the Book of Allah when He created the heavens and the earth, of which four are honorable months. Such is the decree of the right religion, so do not wrong yourselves in the months of honor (in violation of His prohibitions); and fight the polytheists as they fight against you, and know that Allah is with those who guard (against evil). "[3]

Several months referred to in the Qur'an, 9 (AtTaubah): 36 in the words of the Prophet Muhammad SAW as follows

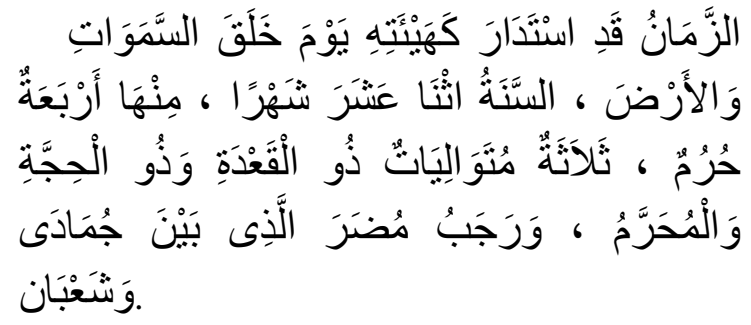

"A year rotates as it has been since Allah created the heavens and the earth. One year has twelve months. Among these are the four haram (holy) months. The three consecutive months are Dzulqo'dah, Dzulhijjah and Muharram.
(One more month is) Rajab Mudhor which lies between Jumadil (end) and Sya'ban. [4]

1. The month of Dzulqa'dah is glorified by Allah SWT because at that time they refrained from war. The month of Dzulqo'dah-Selo is the month for people who are Seneng silo (getting closer to Allah). There are among the previous Kiai / Ulama / Salihin and at this time when the Month of Dzulqo'dah -Selo arrives they try to reduce and / or not move out of the house except in very important and emergency matters. This is because he wants to glorify it by increasing the joy of silos (getting closer to Allah). Fasting was carried out until the month of Muharram (Asy-Syuro).

2. The month of Dzulhijah is glorified by Allah SWT because in this month they go to perform Hajj, and in this month they are busy with various Hajj manasik rituals. Rasulullah SAW in one of his hadiths once conveyed the meaning:

"There are two months in which the merit of charity never decreases, the two months are the month id: the month of Ramadan and the month of Dzulhijjah."

3. The month of Muharram is also glorified by Allah because in this month they return from Hajj to their home country safely and peacefully. The scholars of hadith and the AlQuran as well as Sufi scholars such as Imam Nawawi [5], Imam Suyuthi [6] and Hasan alBasri [7] explain that the month of Muharram is the most glorified month. among the four months that Allah glorified out of the existing twelve months. This is because the name of the month Muharram along with ismul haqq (Allah) becomes Syahru Allahu al-Muharram.

From Abu Hurairah ra, that the Prophet SAW said:

$$
\text { أفضل الصيام بعد رمضنان شهر الله المحرم }
$$

"The best fast after Ramadan is fasting in the month of Allah Muharram"

4. The month of Rajab which is located in the middle of the year is glorified by Allah 
SWT because people who are in the corners of the Arabian Peninsula make a pilgrimage to the Holy House. They came to visit Baitul Haram and returned to their country in peace. "

Apart from that, the Month of Rajab also has an important position in Islam. Because, in this month an event occurred when the Prophet Muhammad was appointed as the Apostle of Allah SWT to the sky, or it is called the Isra 'Mi'raj event. The scholars differed about when this Isra 'Mi'raj occurred.

Asyhurul hurum is recommended by the Prophet Muhammad to perform Fasting and other acts of worship. The glory of Asyhurul Hurum is extraordinary. In those months is the victory of the prophets of Allah SWT.

Linguistically, fasting comes from the word shaum in Arabic which means imsak which means to hold or keep. Meanwhile, in terms of sharia, fasting means refraining from eating, drinking, jima, and everything that invalidates fasting, from dawn to sunset. Fasting in addition to being a shield for a person from acts that violate the Shari'ah, is also one of the forms of slavery to God to achieve His pleasure [8].

In addition to the obligatory fast in the month of Ramadan, Islamic law also recommends sunnah fasting such as fasting on Mondays and Thursdays, fasting of Dawud, fasting on the 13th, 14th, and 15th of the Hijri calendar, and fasting on certain days that are sunnah. However, not only that, boarding schools have a tradition of tirakat fasting as a method to train the control of lust. Among the boarding school, there are many tirakat such as tirakat fasting in the month of dzulhijjah, dzulqo'dah, and Muharram.

In a narration from Ali bin Abi Tholib, Rasulullah saw. said, "There are five things that can eliminate forgetting and increase memory, namely brushing your teeth, fasting, reading the Al-Quran, drinking honey and eating luban. Fasting in a boarding school is used as a physical and spiritual exercise as described earlier, healthily, fasting also has health benefits ranging from eye nerve health, pregnant women, patients with diabetes, renal function disorders, cholesterol and obesity disorders, cortisol hormones, system dawn immunity, patients with peptic ulcer, and patients with cancer [9]. socially, fasting also helps a person in understanding the suffering of those who are less able. With this kind of awareness, then a person who performs tirakat fasting is more able to be patient in every difficult situation, and be grateful for every gift he has, no matter how small. Because the main purpose of fasting is to refresh the consciousness of spirituality [10]. Following the research of [11] which explains that fasting can help them in determining the limits of their actual needs. Besides, they also know themselves better, and calmer in life. While psychologically fasting can control themselves following the research of [12] which explains that the ability to control oneself is a major indication of a healthy and not a person's spiritual life. Psychologically healthy people will have a good level of self-control, thus avoiding various mild mental disorders, especially severe ones.

\section{METHOD}

This study uses a cognitive paradigm with a qualitative approach. Literature review and interview methods were used to obtain research data, both primary and secondary. Primary data were obtained from interviews, while secondary data were obtained from library data sources. The first data collection method used a literature review. The literature used includes books, articles, and trusted websites. The second method of obtaining data is the interview method (interview) or also known as the proficient method. Interviews were conducted with 15 students. The proficient method according to [13] and is used to obtain data through contact in the form of conversations that occur between researchers and sources.[14] Interviews were conducted with santriwan and santriwati Jagad 'Alimussirry Islamic Boarding School. By comparing the various exposures from the 
literature and the results of the interviews, the authors analyze, identify and study to produce a more objective view of tirakat education "Asyhurul Hurum" from an exact, social, and psychological perspective.

\section{RESULT AND DISCUSSION}

This study examines the benefits of Tirakat Asyhurul hurum from a scientific, social, and psychological perspective. This research was conducted by interviewing students of the Jagad Alimussirry Islamic Boarding School Surabaya.

\section{A. Tirakat Asyhurul Hurum from the perspective of Exact science}

\section{Brain health}

At the time of fasting, the energy intake from food, which was normally supplied continuously on weekdays is now largely limited. However, it turns out that there are good things that the brain gets when we fast . Here are some of them: [15]

1. The Source of energy in the brain is obtained from the liver

Glucose is one of the essential nutrients for the brain is only able to meet less than half of the brain's needs. This ultimately forces the body to break down energy reserves in the liver, in the form of glycogen and fatty acids. This condition is good enough for the body because the energy reserves for the brain in the liver will be used so that the body has the opportunity to regenerate or renew energy reserves in the body, especially those in the liver. This condition makes energy reserves in the body better because it is always regenerated.

2. Repair Cells in the Brain

Different energy intake during fasting, in the form of fatty acids, for the brain turns out to be very beneficial. This condition is created because the fatty acids that will be used as energy for the brain undergo a ketosis process which eventually forces the brain to carry out a process of overhaul or autophagy in old cells in the brain. The head of the Center for Neuroscience, Helath, and spirituality (C-NET), said that actually fasting is a mental exercise that is closely related to the nature of the brain, namely neuroplasticity. $\mathrm{He}$ emphasized that brain cells can regenerate and form new structural relationships

3. Improve Brain Function Another benefit of fasting for brain health is that it improves brain function. Changes in the source of energy for the brain during fasting improve brain function in delivering certain signals. This is evidenced by the release of fat as ketones into the blood for energy. Related to that, in the book Ta'lim Muta'allim Shekh Az-Zarnuji said, "The seekers of knowledge should always fast, because by fasting, the brain is motivated to fast, because by fasting, the brain is spurred to concentrate. On the other hand, eating a lot of food can cause phlegm which causes weakness in memorizing." [16] A stomach that is always filled with excess food can overwhelm the cells with food. Thus, it causes the nerves to become moist, the work of the brain is hampered, and by itself intellectual decline occurs, such as being forgetful, weakening reasoning power, and so on. Conversely, when the stomach and stomach are given time to rest or be cleaned of various forms of dirt that have been living for many years, at the same time, the work of the brain can increase and its volume speed increases, so that it can easily solve various problems without experiencing many obstacles.

Based on the results of the interviews, $80 \%$ of the respondents stated that there was a concentration in learning during fasting. This is consistent with the fact that the amount of a protein in the brain called 
BDNF (Brain-Derived Neurotrophic Factor) also increases. Increased protein can improve brain function that regulates behavior, sensory and motor skills, motivation, memory, and learning.

\section{Metabolism during fasting}

Energy sources have different amounts of storage in the body where protein is stored in very limited quantities, carbohydrates are stored in limited quantities, and fat is stored in very large quantities. Each energy source is used under different conditions. Under normal conditions, the use of energy sources starts from carbohydrates, fats, and proteins. During fasting, if the energy produced from carbohydrates has run out, the stored fat reserves will be used as an alternative energy source. This process of breaking down fat is called lipolysis. This is what causes weight loss during fasting because fat reserves in the body have been used. Based on the research, respondents experienced weight loss due to increased metabolic processes.

Some of the respondents do not experience weight loss and the metabolic process remains as usual. This is following several studies, people who do fasting will not reduce the amount of body protein significantly. Fat keeps the process of gluconeogenesis, which is the process of forming glucose apart from carbohydrates, does not use body protein because protein is the last energy reserve.

\section{Immune}

The immune system is a system of the human body that has a function to fight all disease-causing factors such as bacteria, viruses, fungi, parasites, and allergens [17]. One of the immune system markers that can be measured through laboratory tests is an immunoglobulin (Ig) or what is often called an antibody. There are several types of antibodies, namely IgG (gamma), IgA (alpha), IgM (mu), IgD (delta) and IgE (epsilon) [18]. In a study, it was explained that fasting can increase $\operatorname{IgA}$ and $\operatorname{IgG}$ levels [19]. IgG is a type of antibody that has the highest amount in the body so that when it increases, it will strengthen a person's physical condition to fight bacteria or viruses that cause disease. Based on interviews with students at the Jagad Alimussirry Islamic boarding school, the students' immunity increases during fasting.

Based on research conducted by [20] the benefits of fasting for physical health are:

1. Prevent heart disease.

2. Addition of white blood cells.

3. Avoid cancer.

4. Avoid diabetes.

5. Reducing smoking addiction

B. Tirakat Asyhurul Hurum from the Perspective of Social Science

One of the main manifestations of selfcontrol in the implementation of the "Asyhurul Hurum" tirakat education is control overconsumption. Therefore, if this tirakat is applied properly, it will form someone who has good self-control [21]. Based on the results of the interview, it was stated that the students had a sense of empathy for others, social sensitivity, namely feeling empathy if many people outside did not eat and drink because they shared with others so that there would be equality. This is following research conducted by the Faculty of Psychology of Muhammadiyah Surakarta University Students on fasting and social relationship sensitivity which found that fasting was significantly positively related to social sensitivity, meaning that fasting behavior could increase social sensitivity so that with individual sensitivity it became easier to assist (helping behavior) and likes to develop pro-social behavior [22].

C. Tirakat Asyhurul Hurum from the Perspective of Psychology 
Research conducted by Sri Astutik Zulianti revealed that fasting has enormous psychological health benefits, among others;

1. Increasing devotion to Allah SWT.

2. Foster social awareness.

3. Muffle anger.

4. Increase intelligence.

When the digestive system is resting, the brain of a person who is fasting works the other way around, namely when the digestive system is resting, the brain is managing a lot of information. Because the brain is able to remember well when someone is calm and relaxed. In Islamic literature there is the term nafs almuthmainnah (quiet soul). Calmness can make someone less reactive when facing problems. With this calm, he is able to think well and has a very sharp heart.

Dr. Taufik Parsiak said that fasting is a form of purification of lust (tazkiyatun) and educating desire (tarbiyatun iradah). Therefore, when a person does fasting in earnest, the behavior during fasting and the rituals carried out is always in an effort to improve lust, cultivate, then manage the various wills within oneself.

Based on interviews with students who fasted Asyhurul Hurum, as many as $100 \%$ of respondents stated that fasting can increase devotion to Allah SWT because fasting is a very good practice, in addition to fasting students perform dhikr to Allah with wirid-wirid that has been determined by murshid kamil.

Another study related to fasting [23], found that fasting has a positive relationship with anger regulation. The more individuals fast, the higher the level of anger regulation, and vice versa, the less often the individual fasts, the lower his anger regulation will be. Based on this research, it can be concluded that individuals are encouraged to fast continuously, because it can be used as a way to train themselves to control emotions, especially anger regulation. Based on interviews with students who fasted Asyhurul Hurum, as many as $100 \%$ of respondents stated that fasting can provide peace of mind. This is consistent with the research conducted by [24] which found a positive correlation between the quality of fasting and the happiness of students. The results of this study explain that when the students are fasting, they tend to avoid bad behavior, always be patient, behave following Allah's will, this causes positive emotions and life satisfaction, so it can be concluded that the more quality the fast is carried out, the higher the happiness they feel. and following research that fasting can also increase one's emotional intelligence. [25]

\section{CONCLUSION}

The results of this study can be concluded that there is a relationship between tirakat asyhurul hurum with exact, social, and psychological knowledge because tirakat asyhurul hurum contributes to multidisciplinary science. Inexact science, Tirakat Asyhurul Hurum can increase concentration in learning, increase metabolism, and increase immunity. In social terms, Tirakat Asyhurul Hurum can increase the feeling of empathy for others, and Tirakat Asyhurul Hurum. in psychologically able to improve emotional intelligence in a person.

\section{REFERENCES}

[1] Geertz, C. 1973. The interpretation of cultures: Selected essays. New York: Basic Books.

[2] Pusat Bahasa Departemen Pendidakn Nasional. 2005. Kamus Besar Bahasa Indonesia. Jakarta: Balai Pusataka. Edisi ketiga.

[3] Q.S At-Taubah: 36

[4] HR. Bukhari No. 3197 dan Muslim No. 1679.

[5] Imam al-Nawawi, 'Al Minhaj Syarhu Shohih Muslim bin al Hajjaj', 8/55. 
[6] Imam al-Suyuthi, Syarh Suyuthi 'Ala Shahih Muslim, 3/252.

[7] al-Imam, al-Hafizh, al-'Alim Zainuddin 'Abdurrahman bin Ahmad bin 'Abdurrahman bin al-Hasan bin Muhammad bin Abu alBarkat Mas'ud as-Salami al-Baghdadi adDimasyqi al-Hanbali, Lathaif al-Ma'arif Fima li Mawasim al-Ami Min al-Wadhaif (Damasyqi Bairut: Dar Ibn Katsir, 1999), 34.

[8] Saputra, Johan. 2018. Ngrowot dan Tazkiyatun Nafs (studi Manfaat Ngrowot untuk Pembersihan Jiwa di Kalangan Santri Asrama Perguruan Islam (API) Pondok Pesantren Salaf Tegalrego Magelang Jawa Tengah), Skripsi Fakultas Ushuluddin Universitas Islam Negeri Sunan Kalijaga Yogyakarta, hal. 18

[9] Subrata, Sumarno Adi dan Dewi, Merses Varia. 2017. Puasa Ramadhan Dalam Perspektif Kesehatan: Literatur Review. Khazanah: Jurnal Studi Islam dan Humaniora. Vol 15. No. 1.

[10] Ahmed, Akbar S. 1997. Living Islam: Tamasya Budaya Menyusuri Samarkand hingga Stornoway, diterjemahkan dari "From Samarkand to Stornoway: Living Islam” oleh Pangestuningsih. Bandung: Penerbit Mizan

[11] Hidayati, Nurul. 2020. Riyadhah Puasa Sebagai Model Pendidikan Pengendalian Diri untuk Pemenuhan Kebutuhan Fisiologis. Millah: Jurnal Studi Agama. Vol. 20, No. 1

[12] Arifah, Lailatul. 2018. "Ngrowot" Tirakat In Exact Science Perspectives, Social And Psychology. Journal Intellectual Sufism Research. Vol. 01 No. 01.

[13] Mahsun. 2012. Metode Penelitian Bahasa: Tahapan Strategi, Metode, dan Tekniknya (sixthed). Jakarta: Rajawali Press

[14] Sudaryanto. 1988. Metode Linguistik. Yogyakarta: Gadjah Mada University Press.

[15] https://www.halodoc.com/artikel/ketahuimanfaat-puasa-untuk-kesehatan-otak.

[16] Az-Zarnuji, Syekh. 1990. “Ta'lim alMuta'allim Thoriq al-Ta'allum”. Semarang: Toha Putra

[17] Alberts, B., Johnson, A., \& Lewis, J. (2002). Molecular Biology of the Cell (4 ed.). New York: Garland Science

[18] Schroeder, H. W., \& Cavacini, L. (2010). Structure and Function of Immunoglobulins.
The Journal of Allergy and Clinical Immunology,

[19] Bahijri, S., Ajabnoor, G., Borai, A., Al-Aama, J., \& Chrousos, G. (2015). Effect of Ramadan fasting in Saudi Arabia on serum bone profile and immunoglobulins. Therapeutic Advances in Endocrinology and Metabolism.

[20] Sri Astutik Zulainaty. Manfaat Puasa Bagi Kesehatan Fisik dan Mental: Studi Pemikiran Imam Musbikin, Yogyakarta: Fakultas Dakwah UIN Sunan Kalijaga, 2006.

[21] T. Haryono. 2016. "Puasa Sebagai Tirakat Sosial".https://www.spi.or.id/puasasebagaitirakat-sosial/. Diakses tanggal 17 Februari 2017.

[22] S. Bukit. 2013. "Puasa dipandang dari sudut psikologi”. Diambil dari http://sumut.kemenag.go.id/file/file/TULISA NPENGAJAR/ovj11374463509.pdf.

[23] Julianto, V., \& Muhopilah, P. (2015). Hubungan puasa dengan tingkat regulasi kemarahan. Jurnal Ilmiah Psikologi, vol 2 No 1

[24] Muhopilah, P., Gamayanti, W., \& Kurniadewi, E. (2018). Hubungan kualitas puasa dan kebahagiaan santri Pondok Pesantren Al-Ihsan. Jurnal Psikologi Islam dan Budaya. Vol 01 No. 01

[25] Aqiilah, Izzatul Ikhda. 2020. Puasa Yang Menajubkan (Studi Fenomenologis Pengalaman Individu Yang Menjalankan Puasa Daud). Jurnal Empati Vol 9 No. 2 